\title{
HAPPY AND HEALTHY: \\ THE HYPOTHESIS OF CORRELATION BETWEEN SUBJECTIVE WELL-BEING AND PSYCHOLOGICAL HEALTH AND ITS ROLE IN LATE ADULTHOOD
}

\author{
IRYNA HORBAL \\ iryska.ambivalence@gmail.com \\ Ivan Franko Lviv national University \\ Ukraine \\ ABSTRACT
}

Subjective well-being as an emotional-cognitive assessment of person's life is an important aspect of psychological health and positive functioning in general. The hypothesis of connection between subjective well-being, psychological well-being and psychological health is presented. This correlation is very important in late adulthood for ensuring happy obsolescence but has some specific peculiarities due to the elderly people's age and individual traits. Subjective well-being is a background for effective inner work of summarizing person's previous life that is the main purpose in old age.

Key words: subjective well-being, happiness, psychological well-being, psychological health, old-aged people, late adulthood.

Distinguishing a period of gerontogenesis and studying of elderly people's problems are explained by a complex of social, economical, biological and psychological factors. Gerontology is a scientific area which studies the peculiarities of inner world and running of mental processes of elderly people. It also gives information about the motives and needs that appear in late adulthood and, thus, the opportunity to understand the ways and causes of elderly people's emotional reactions to different life circumstances. During the last years the emphasis in gerontology (and gerontopsychology as well) was changed. Scientists do not still try to avoid the decrease of constitutional functioning caused by obsolescence. They attempt now to provide optimal aging according to the old-aged people's peculiarities.

Subjective assessment of person's life (together with objective indexes of emotional and cognitive processes) is one of the main indicators of optimal personal functioning in psychology. Subjective well-being causes a lot of interest among scientists of ethics, theology, political science, economy, psychology etc. in recent decades. According to such diversity there are many close concepts that illustrate different aspects of this phenomenon: "happiness" (Lyubomirski 2008 and others), "psychological well-being" (Ryff, Singer 2008 and others), "quality of life" (Ventegodt, Merrick, Andersen 2003 and others), "emotional comfort" ("emotional balance") (Bradburn 1969 and others), and "satisfaction with life" (Diener 1985 and others). Although each term has its semantic peculiarities, there is one basis for all these concepts - persons' attitudes to different aspects of their functioning are reflected. On the one hand, these attitudes are formed due to the 
objective circumstances and individual characteristics; on the other hand, they affect personal life.

Distinguished by positive psychologists the phenomenon of subjective well-being is studied in the context of the ability to realize personal potential, to positively function, to be authentic, to feel the sense on life etc. All these features characterize the state of psychological health as well. The feeling of happiness as a general complex estimation of well-being in different life areas is a final aim of all psychological and psychotherapeutic interventions and programs of psychological accompaniment. It is widely studied in psychology together with different personal characteristics and aspects of positive functioning.

The aim of the study is threefold. Firstly, it is important to find out what the phenomenon of subjective well-being is, why it is distinguished from the close concepts and what the psychological correlates of such subjective assessment of life are. Secondly, we are interested in the link between well-being and psychological health. Finally, the task is to show the peculiarities of elderly people's subjective well-being and its role in determining health. All this should help to understand what the main factors of feeling good and healthy in late adulthood are and what psychological peculiarities are needed to be developed with young people for their happy future aging.

\section{PSYCHOLOGICAL MEANING OF SUBJECTIVE WELL-BEING}

"Well-being" in the wide sense is considered to be the multicomponent construct of cultural, social, psychological, physical, economical, and spiritual factors (Tvorogova 2007). However, this definition does not give any information about psychological meaning of the phenomenon and the ways one may explain, understand and influence on it. Moreover, objective indicators of well-being (health, financial state, success etc.) influence only indirectly on the experience of well-being. It is more importantly defined by the person's attitudes to oneself, to the world around in general and its different spheres. Psychologists are more interested in the subjective perception of all the factors which are described by a terms "subjective well-being".

Concepts of "subjective well-being" and "happiness" are sometimes used interchangeably. The term "happiness" is very contradictory, however, and due to its everyday usage is considered as an inexact phenomenon of existential aspect of people's lives. There are some separate ways of understanding happiness in psychology. On the one side, is treated as a complex of ideals (standards) of human life (Kulikov 2000, p. 507) to which a person compares his or her life and the lives of others. Considering happiness as a value, Inna Dzhydarian showed that unlike the other human values it has not got its self essence, 'goes through' the other values and is a 'by-product' of their realization (Dzhydarian 2000, p. 48). It is close to the Viktor Frankl's ideas about sense and meaning of human life. The concentration on something concrete (power, money, love, satisfaction, health etc.) does not only cause noogenic neurosis as a loss of life meaning but also reduces an opportunity to feel happy. "...happiness cannot be pursued; it must ensue. One must have a reason to 'be happy'. Once the reason is found, however, one becomes happy auto- 
matically. As we see, a human being is not one in pursuit of happiness but rather in search of a reason to become happy" (Frankl 2006, p. 61).

Some investigators (Argyle 2001, Csikszentmihalyi, Mei-Ha Wong 1991) define "happiness" more narrowly, as an affective component of subjective well-being. It is claimed that happiness is an emotional state when a person feels inner contentment with the circumstances of life, fullness and meaningfulness of life and realization of his or her appointment (Gulyas 2010, p. 104). However, this definition of happiness also contains the need of positive understanding of one's life (Gulyas 2010, p. 104) that is a rather cognitive not emotional aspect. Moreover, after asking people what do they mean by "happiness" scientists found out that some respondents describe it in emotional terms (like "joy") while the others use cognitive words (like "satisfaction") (Argyle, Martin 1991, p. 77).

Thus, the estimation of life is usually made on two levels - what a person feels and thinks about the situation he or she is living in and the place he or she is taking in it. According to this idea psychologists of the hedonistic approach describe two dimensions in modeling of subjective well-being. "Affective" dimension comes out of the balance of positive and negative emotions. A happy person experiences many positive affects and a few negative ones. "Cognitive" dimension contains a notion of how a person is satisfied with life, how does it coordinate to his or her ideal standard (Argyle, Martin 1991, p. 77-79; Argyle 2001). Each of the components is determined by many factors - economical, social, bodily, personal etc. Nevertheless, individual traits play the main role in forming of life satisfaction and subjective well-being in general. It is also claimed that personal peculiarities remain a relatively stable level of these indicators over long periods of time (Diener, Larsen 1984).

Scientists of existential phenomenological psychological approach usually operate with the term "psychological well-being" which is close but not similar to "subjective well-being". "Psychological well-being" is defined as a system of personal traits which is evolved during person's life and manifests in profound feeling of the life importance in general as an instrument for achieving inner socially oriented purposes and is the condition for realization of capabilities and potentials (Voronina 2002, p. 5). Carol Ryff highlights that experiencing of psychological well-being in developmental psychology is considered as a trajectory of continued growth across the life cycle (it is seen from Erik Erikson's psychosocial stages, Charlotte Buhler's basic life tendencies, Bernice Neugarten's personality changes). Clinical psychologists describe it through Abraham Maslow's conception of selfactualization, Gordon Allport's formulation of maturity, Carl Rogers' depiction of the fully functioning person, and Carl Gustav Jung's account of individuation. Finally, mental health literature includes not only negative descriptions of psychological functioning but also some expositions of positive health (Ryff 1995, p. 720). Altogether, the meaning of "psychological well-being" is focused on the feelings and states that characterize a healthy person.

Thus, despite some close aspects, there are some essential differences of the concepts of "subjective" and "psychological well-being". Subjective well-being contains those emotions and thoughts that form person's general attitude and idea of his or her life. Psychological well-being is more widely meant and includes 
intentional components, the possibilities of further personal development. In this case psychological well-being seems to be the next stage in realizing of person's positive functioning. After creating the attitude to oneself and to the world around, the person chooses the ways of interaction with the world and self-realization in it. Thus, psychological well-being is close to psychological health but the ways of manifestation are different. The first construct is meant to be a subjectively evaluated measure of realization on one's potential while the second shows the factual, objective result of this realization.

Hence, subjective well-being is identified as a dynamic cognitive and emotional person's assessment of general life quality and quality of its separate spheres. It is formed on the basis of objective factors (circumstances of life and activity, contentment of basic needs, health status etc.) that are perceived and assimilated by the personality according to his or her individual peculiarities (temperament, character, life orientation, self-estimate, self-acceptance, value orientations etc.). On the one hand, subjective well-being is the important prerequisite of the person's ability to realize self-potential and to positively function. On the other hand, the ability to self-realization influences a lot on person's self-attitude and attitude to the circumstances he or she lives in.

\section{WELL-BEING AND PSYCHOLOGICAL HEALTH}

Health psychology as a sufficiently young area of science that concentrates on the integrative model of health, on the understanding nature of health as a combination of not only medical and biological but also social, economical, philosophical, individual and other peculiarities. Psychological health as a separate aspect of positive man's functioning emphasizes that a person is not only a biological creature but also a personality with the unique traits that define person's life.

World Health Organization (WHO) defines "health" as a "state of complete physical, mental and social well-being and not merely the absence of disease or infirmity" (WHO, 1948). This formulation is usually criticized for its idealistic and static character but it is consequentially to consider health in three main dimensions: physical, social, and mental. However, if physical dimension of health is well-studied and has precise criteria, there is no such monosemantic position on the rest two issues. Not being a separate unit, psychological health is usually studied as a part of mental health. Besides investigating the properties, peculiarities, mechanisms and patterns of mental disorders it is important to study these mental processes and phenomena on the individual level when there is no pronounced pathology (Haletska 2006, p. 93). Thus, mental health is seen in two aspects. Structural-procedural aspect is concerned to the mental activity, characteristics of cognitive and emotional processes and peculiarities. Properly psychological context of mental health comprises attributes of person's value-motivational and noogenic spheres, beliefs, Ego-properties and identity, spiritual sphere (Haletska 2007 , p. 319). In another study, concepts of "mental health" and "psychological health" are separated: the first is related to specific mental processes and mechanisms, while the second belongs to the whole person, "is in close correlation with the highest expression of the human spirit" (Dubrovina 2000, p. 6). Psychological health is considered as 
a state, balance between the different aspects of human personality (Assagioli 2000), consistency between individual and social needs supported by constant conditions (Fraiberg 1980) and as a life process in which reflexive, emotional, intellectual, communicative, and behavioral aspects are balanced (Cholmogorova, Gagaryan 1999; Ananiev 2006, p. 38). Thus, psychological health unlike mental health is a manifestation of personality's individual integrity and ability to implement capabilities, not just a characteristic of various mental processes functioning. It may be called an integrative component, personal outcome of mental, social and physical health.

The question of psychological health criteria is considerable. The characteristics by which one can determine whether a person is physically or mentally healthy are largely established. There is, however, no such uniqueness about the balance on value-semantic, personality traits. Considering psychological health both as an implementation and a factor of personality socialization and development, researchers define its main criterion as adaptability. It manifests itself not only in objectively diagnosed balance or subjective experiencing of social situation contentment, but also in the absence of negative emotional, behavioral and personal effects in the future and personal development (Ababkov, Perre 2004). This aspect approximates the concepts of "psychological health" and "subjective well-being". In the cognitivebehavioral interpretation adaptation as a basis for psychological health is defined in terms of actions or behavior as "specific manifestations of human life". Like subjective well-being, psychological health determines how external circumstances and internal dispositions influence on the person's psychological state. "Subjective wellbeing" is person's own self-attitude and life attitude while "psychological health" reveals objective manifestations of mental processes and states.

Another aspect in understanding of psychological health belongs to the existential-humanistic psychological tradition. Its vision of the phenomenon is identified with the concept of personal maturity. The level of psychological health is defined by functional resources and flexibility, the ability to self-transcendence, self-acceptance and acceptance of others. The main criteria for psychological health according to this vision are similar to the criteria of personality's internal freedom. These are prudence, spiritual independence, self-control, ability to discover, maintain and develop intrapsychic and interpersonal balance (Haletska 2010, p. 131). Psychological health does not only determine the possibility of adapting to changing real condition. It also defines the anticipation of possible consequences and changes together with self-realization and self-development of personal identity.

Criteria of psychological health determined on the generalization of cognitivebehavioral and existential-humanistic concepts combine various behavioral patterns and personality dispositions. They manifest at different levels of individual functioning, from the interaction with the environment to own spiritual dimension (Haletska 2006, p. 131). Psychological correlates of subjective well-being substantially coincide or closely relate to them. The emotional background of mood is associated with life satisfaction (Schwarz, Strack 1991, p. 36), although it is clear that this effect on well-being is short. Along with behavioral displays, emotional reactions to various life situations are the indicators of psychological health (Haletska 2006, p. 117). Personality traits determine somewhat more stable state of subjective life assessment. "Cognitive" component 
of subjective well-being is correlated with high extraversion, low neuroticism, openness to experience, strong sense of social support. Individuals who often experience positive emotions usually are extraverts, opened to experience, have a good social network and high social status (Headey, Wearing 1991, p. 57-59). Peter Lewinsohn and colleagues emphasize the role of the relative absence of intrapsychical conflicts, involvement in meaningful activities, the presence of friends and family (it is especially important for men to be married), satisfaction with family life, high level of education, financial security and physical attractiveness for increasing of subjective well-being (Lewinsohn, Redner, Seeley 1991, p. 143). Elena Knyazeva found out that satisfaction with life is related to extroversion, self-confidence, ability to take responsibility for one's own actions, and sense of internal control over events in life (Knyazeva 2011, p. 163).

Attributive styles of happy people are proved to be somewhat different from those of unhappy ones. It is revealed that people with high subjective well-being perceive positive events in their lives as global, stable and those that occurred due to person's own activity. People with low levels of welfare interpret negative events this way. The first perceive situations in life in general as pleasant and recall happy moments more often. Happy people are characterized by the internal locus of control and belief that events are under their own control (Argyle, Martin 1991, p. 93). In our studies we have found out that individuals with high levels of satisfaction with life perceive their lives more cheerfully and positively, they have a high level of optimism (Horbal 2012a, p. 182).

Psychological well-being as the resulting, self-affirming manifestation of subjective well-being is closely correlated with the status of identity, capacity for emotional regulation, personal goals, values, effective coping strategies, social support and social status, education level and objective and self-estimated state of health (Ryff 2008, p. 26-27), indicators of self-regulation, level of personal maturity, ability to develop own potential (Alexandrov 2009), presence of purpose in life, sense of meaningfulness of the past and present life, focus on something in the future (Shamionov 2006, p. 107-108), namely with different existential psychological characteristics.

Among the criteria of psychological health many features are semantically identical or closely linked to personal characteristics described above, mainly to the correlates of psychological well-being. These are effective coping strategies, adequate psychological defense mechanisms functioning flexibility to respond to various stimuli, optimism, sense of humor, creativity, intelligence, sense of self-efficacy, Ego-identity, self-esteem, feeling on the way or on the top of self-actualization, experience the presence of life meaning, feelings of coherence and many others (Haletska 2006, p. 117119). Ruut Veerhoven (1991) indicates that those features which are associated with psychological health and harmonious personal development and which are the goals of many psychotherapists are also determinants of happiness. Integrated identity, Ego-strength, mental maturity, internal control, social ability, activity, openness perception and experience are among them (Veerhoven 1991, p. 19).

Psychological health is the embodiment of social, emotional and spiritual wellbeing (as a resource and state). It is a potential prerequisite for providing the life necessities for the active lifestyle, achievement of one's own goals, adequate and optimum interaction with people, social environment and other (Haletska 2006, p. 94). Thus, "subjective well-being" is a construct focused on the personal assessment of 
functioning in various spheres of life and opportunities to continue self-development. "Psychological health" is meant to be a concrete measure of the ability to implement person's potential. Thus, subjective well-being should be considered as one of the prerequisites, the preliminary stage on the way to self-realization of the individual.

On the other hand, it is important to note that the presence of objective health indicators and subjective satisfying perception of it improve person's subjective well-being (Cho, Martin, Margrett, MacDonald, Poon 2011, p. 5). When a person experiences health on all levels - physical, social, mental, including psychological his or her emotional perception of reality becomes better (because the attitude is a part of subjective reality and the results of its implementation are part of objective reality), together with a cognitive assessment. In this sense, subjective well-being as an integrative personal assessment of life quality can be seen as a consequence of the harmonious functioning of mental processes and realizing personal potential.

To sum up, the general idea of interaction between subjective well-being, psychological well being and psychological health is created. Subjective well-being is meant to be an emotional-cognitive assessment of life, those emotions and thoughts that a person has about his or her life. This is an attitude to life a person lives and a background to the attempts of making something for its further development. A small distance between the evaluation of person's real life and Self and his or her image of ideal living and Self motivates to reach higher goals, to grow and to develop. The embodiments of subjective well-being are psychological well-being and psychological health. The first is meant to be person's subjectively evaluated measure of realization self-potential, self-growth, ability to positively communicate with others and to be autonomous simultaneously etc. Psychological health is defined as a complex of real indicators of person's self-development and self-realization. It is also important to understand that all of these constructs are dynamic which means that they are not stable and develop in time due to the external factors they (and mainly subjective wellbeing) depend on. These indicators are interacting in different directions. Psychological well-being and health as the measures of how well does a person realize his or her self-development also influence on how is his or her background evaluation of life changes. If there are all the conditions for self-growth and a person uses them in the right way, there is a reason for positive emotions and judgment of life as close to the ideal which makes a background for further life improvement.

\section{LATE ADULTHOOD: WHY SUBJECTIVE WELL-BEING IS IMPORTANT}

The first two parts of the article are dedicated to the issue of subjective well-being in general, as a psychological concept and a subject of scientific researches. A special role the experiencing of happiness plays in late adulthood. Elderly people usually face a lot of social and psychological difficulties: the necessity to re-socialization and adaptation to a new social role and limited capabilities of the organism.

A part of subjective well-being determinants described in the second chapter surely may be extended to old-aged people. However, while analyzing the peculiarities of personal and social development in late adulthood, there appears a need of revising of study results among this age group. 
Time orientation in old age is mainly directed in the past, elderly people live in their memories (Yermolayeva 2002, p. 100-105). In contrast, life satisfaction of youth is directed in the future and is connected with planning, creating aims and dreams. Life meaning in late adulthood partly changes: the leading activity is a special 'inner work' of accepting one's life span, comprehension of present and past experience that is linked to a healthy obsolescence (Liders 2000, p. 7). The main target of late adulthood, after Erik Erikson, is the necessity of believing life a person has lived was not useless and has its value (Erikson, Erikson, Kivnick 1986). Thus, personal functioning in old age is determined by an assessment of value and importance of life, the life meaning accent is shifted from future and present to past.

Affective sphere that determines some aspects of subjective life assessment changes in late adulthood. The abilities to emotional regulation decrease, emotional reaction threshold becomes lower, emotional response narrows, a person becomes detached (Yermolayeva 2002, p. 138-156; Chuchlayeva 2002, p. 140-176), depressive traits form the emotional background, a person often expresses many fears (fear of death, disease, future etc.) (Craig, Baucum 2005, p. 767-770) and loneliness (Yermolayeva 2002, p. 139-152). All this largely complicates the abilities of social interaction. Difficulties with emotional control and aggravation of personal traits may worsen the quality of communication with others. A permanent need of feeling and understanding self-importance (Craig, Baucum 2005, p. 775) limit the ability of getting positive emotions while communicating with others. This also influences on subjective well-being because the quality of social contacts is an important component of high life estimation.

One more important life sphere that is closely connected with subjective wellbeing is professional self-realization. On the one hand, retirement that matches in time with a period of late adulthood leads to the limitation of interaction circle, formalization of communication with colleagues etc. Moreover, old-aged person feels that other people do not need his or her help as it was before, concludes that his or her personal value for a society becomes smaller. This prevents getting used of a person to a new social status. On the other hand, retirement gives senior people an opportunity to spend their free-time as they want, to become drawn into activities they had no time for during their active professional self-realization.

Clarification of social-psychological context of old-aged people's lives gives a proof that it is important to separately study subjective well-being among this category of respondents. Carol Ryff had found out that there are some significant differences in personal understanding of happiness and its determinants among senior and middle-aged people. The most important factors of first age group's happiness are family relationships, quality of communication with husband or wife, children and other family members. These are also the most usually named determinants for middle-aged respondents. However, the next stages are much more different. Health is the second essential factor of elderly people's subjective well-being while it is one of the most unimportant for younger respondents. Senior people feel happy having an opportunity to be involved in different activities like social work, volunteering, church etc. While job is one of the most rarely named as a determinant of subjective well-being in late adulthood, it was the second urgent for middle-aged respondents (Ryff 1989, p. 197-199). However, this 
study shows the influence of people's attitudes to different life sides that reveals only one of the aspects of subjective well-being. Some studies are concentrated on the psychological peculiarities that determinate happiness in late adulthood.

After reviewing some literature dedicated to the theme, a system of psychological correlates of elderly people's subjective well-being was created. It was claimed that subjective assessment of life quality contributes to the feeling of being younger than a person's chronological age is. People whose subjective age is lower than the real age declare that their memory and general health are better (Stephan, Caudroit, Chalabaev 2011, p. 432-433). Social functioning in late adulthood is essential. Having an opportunity to choose their social circle and interact with those who evoke positive emotions (social selectivity) (Charles, Carstensen 2010, p. 390), the ability to give and receive social support during this interaction and willingness to spend time with people (social interest) (Sener 2011, p. 85-86) provides not only the collection of old age contradictions and slowing of aging process, but also a subjective sense of happiness. Some researchers claim that satisfaction with a job a person was involved in before retirement is another important social factor of high life evaluation in old age (Craig, Baucum 2005, p. 772). Although it was shown that the factor is not main in determining of happiness, in the younger age job was an important part of person's life and the level of self-realization in it may play a role in general life satisfaction.

Experiencing of subjective well-being in old age is connected with some personal traits but there are only a few studies dedicated to the theme. It was found out that happiness and person's religiosity (especially among women) are correlated. The low sense of loneliness became an important indicator for both sexes (Sharma 2011, p. 38). While studying the peculiarities of senior people's value sphere in predicting the level of subjective well-being we have found an association of life satisfaction with the value of achievement (Horbal 2012b, p. 40). Perhaps the presence of wish to get something in life even after getting old gives a person the direction for future and a feeling of active taking part in life. In another investigation high subjective well-being was proved to be linked with a high level of hardiness as the ability to maintain internal balance in stressful situations (Horbal 2012a, p. 40). As it was noticed before, late adulthood is a period where many stressful situations appear (retirement, restriction of contacts with social groups, death of close people etc.) that's why person's capability to cope with stresses is needed for experiencing positive emotions, one of the conditions of being happy. Finally, subjective well-being of elderly people appears due to the optimistic perception of life, the ability to perceive it as happy, cheerful, positive etc. (Horbal 2012a, p. 40).

Some aspects of health in old age are closely related to subjective well-being. Memory is important for realizing of the main aims of late adulthood, for 'fixing' past events and for making conclusions about the life results. If the functioning of cognitive sphere is well from person's point of view, the satisfaction with life becomes higher. The subjective assessment of health in general is important: if a person feels healthy, his or her happiness will grow (Stephan, Caudroit, Chalabaev 2011, p. 432). The connection of happiness and objective health indicators is also studied. Physical health, lack of discomfort in the body in late adulthood play an important role in ensuring wellness, this is the condition of positive experiences (Cho, Martin, Margrett, MacDonald, Poon 2011, p. 4). It is reasonable to assert on the reverse connection. Happiness is related to numbers of 
positive emotions and positive opinions about the life and own personality. Thus, it is accompanied by better resistance to stress and prevents physical diseases caused by psychogenic factors (for example, psychosomatic disorders). Susan Turk Charles and Laura Carstensen highlight that positive emotions in young age prevent quick death. Different medical indexes, blood pressure and the state of the immune system depend on person's mood (Charles, Carstensen 2010, p. 386). Elderly women that declare they have a low level of emotional support die faster than those who are more successful in this sphere (Lyyra, Heikkinen 2006, p. 150-152). Due to another study the correlation of this indexes is also correct for male respondents (Pressman, Cohen 2005, p. 925-971).

Therefore, well-being in late adulthood is also connected with all main factors of general wellness but it is embodied in somewhat different aspects of human life. In the ideas described in the first two chapters, subjective well-being is connected with person's subjective feeling and real abilities of self-realization, personal growth and development. According to the peculiarities of old-aged people it is important to highlight that the feeling of subjective well-being is mainly important for realizing targets of late adulthood, for finding out what was good in the past and what they have lived life for.

\section{CONCLUSIONS}

The work was dedicated to the theme of subjective well-being, its notion in modern psychology and its place in old-aged people's lives. The concept of subjective well-being becomes more and more popular among psychologists. The study of this phenomenon has got not only theoretical but also practical importance. The discovery of objective indicators of personal comfort and subjective positive vision are important goals in the context of any psychoconsultative and psychotherapeutic interventions. Moreover, it has to become the main objective, the basic direction of work of a practicing psychologist.

While analyzing different approaches to understanding well-being in psychology the main aspects of this phenomenon were found out.

Firstly, subjective well-being is personal assessment of life quality. Although it is formed due to not only subjective but also objective factors, the context of subjective wellness that is studied in psychological researches is determined by the reflection of these two groups of factors in the individual consciousness.

Secondly, many close but not equal to "subjective well-being" terms appear in modern psychology. It seems to be reasonable to use constructs of "happiness" and "subjective well-being" as permutable. We also use a term "subjective evaluation of life quality" as a descriptive equivalent to the construct of "subjective well-being".

Thirdly, we have made an attempt to find out the connections between concepts of "subjective well-being", "psychological well-being" and "psychological health" as different aspects of people's positive functioning. Understanding these concepts as dynamic multicomponent phenomena, we consider "subjective well-being" to be a background to person's further self-growth. It is embodied in two levels: self-rated which is called "psychological well-being" and factual which is named "psychological health". 
Finally, psychological correlations of subjective well-being among old-aged people were studied. It was found out that there are some important indicators of high subjective evaluation of life quality in social and personal spheres. These are good interaction with family members, feeling younger than a person really is, high hardiness and optimism, high subjective health and good objective indicators of it, etc. The last two factors do not only determinate happiness but also are predicted by it: happy people usually rarely feel sick and feel healthier more often. The embodiments of subjective well-being in late adulthood are not totally the same in young age: senior people use high evaluation of life for going through the crisis of old age, for creating a general positive image of the past life. Only after understanding their life is meaningful and important they continue further personal growth.

\section{LIMITATIONS}

We would like to ask the reader to perceive the author's thoughts presented in the article as a hypothesis but not a fact. The theme is very disputable and there appears no unique accepted point of view on the phenomenon of subjective well-being. Hence we were trying to highlight (hypothetically) the most important aspects and to demarcate close but not similar concepts of people's positive functioning. The biggest limitation of the study is connected to the question of correlation between subjective well-being, psychological well-being and psychological health in general and its age peculiarities. All the conclusions described in the article are now only theoretical model. It is needed to check its validity and reliability with empirical study. Thus, the next stage in this study has to be the investigation of the concept of positive functioning in general and its manifestation in late adulthood.

\section{BIBLIOGRAPHY}

Ababkov V. B., Perre M. (2004), Адаптация к стрессу. Основы теории, диагностики, терапии (еп. Adaptation to stress. Basis of theory, diagnostics, therapy), Речь, St. Petersburg.

Ananiev V. А. (2006), Основы психологии здоровья. Книга 1. Концептуальные основы психологии здоров'я (en. Basis of health psychology. Book 1. Conceptual background of health psychology), Речь, St. Petersburg.

Argyle M. (2001), Psychology of Happiness, Routledge, London.

Argyle M., Martin, M. (1991), The Psychological Causes of Happiness, [in:] Strack F., Argyle M., Schwarz N. (eds.), Subjective Well-Being: an interdisciplinary perspective, $1^{\text {st }}$ ed., Pergamon Press, Oxford.

Assagioli R. (2000), Psychosynthesis: A Collection of Basic Writings, Synthesis Center, Amherst, MA.

Bolshakov V.O. (еd.) (2000), Общество и политика: Современные исследования, поиск концепций (еп. Society and politics: modern studies, search of concepts), Издательский дом СПбГУ, St. Petersburg.

Bradburn N. M. (1969), The structure of psychological well-being, Aldine, Chicago.

Charles S. T., Carstensen L. L. (2010), Social and emotional aging, "Annual Review of Psychology" 61.

Cholmogorova A. B., Gagaryan N. G. (1999), Эмоциональные расстройства и современная культура (на примере соматоформных, депрессивных и тревожных расстройств) (en. Emotional disorders and modern culture (on the illustration of somatoform, depressive and anxiety disorders), "Московский психотерапевтический журнал" (en. "Moscow psychotherapeutic journal”) 2.

Chuchlayeva O. V. (2002), Психология развития: молодость, зрелость, старость (еn. Developmental psychology: juvenility, maturity, senility), Академия, Moscow.

Craig G., Baucum D. (2005), Психология развития (еn. Developmental psychology), Питер, St. Petersburg.

Csikszentmihalyi M., Mei-Ha Wong M. (1991), The Situational and Personal Correlates of Happiness: A Cross-National Comparison, [in:] Strack F., Argyle M., Schwarz N. (eds.), Subjective Well-Being: an interdisciplinary perspective, $1^{\text {st }}$ ed., Pergamon Press, Oxford. 
Diener E., Larsen R. J. (1984), Temporal Stability and Cross-Situational Consistency of Affective, Behavioural and Cognitive Responses, "Journal of Personality and Social Psychology" 47.

Diener E. (1985), The Satisfaction With Life Scale, "Journal of Personality Assessment" 49 (1).

Dubrovina I. V. (ed.) (2000), Психическое здоровье детей и подростков в контексте психологической службы (en. Mental health of children and adolescence in the context of psychological service), Деловая книга, Yekaterinburg.

Dzhydarian I. A. (2000), Счастье в представлениях обыденного сознания (еп. Hарріnеss in representation of trivial sense), "Психологический журнал" (en. Psychological journal) 21 (2).

Erikson E. H., Erikson J. M., Kivnick H. Q. (1986), Vital involvement in old age, Norton, New York.

Fraiberg S. (1980), Clinical studies in Infant Mental Health, Basic Books, New York.

Frankl V. (2006), Man's Search of Meaning, Beacon Press, Boston.

Gulyas I. A. (2010), Феномен щастя: аксіопсихологічні аспекти (еn. Phenomenon of happiness: axio-psycological aspects), "Проблеми загальної та педагогічної психології", (en. "Problems of general and pedagogical psychology"), Збірник наукових праць інституту психології ім. Г. С. Костюка НАПНУ XII (4).

Haletska I. I. (2006), Психологічне здоров'я (еп. Health psychology) [in:] Haletska I., Sosnowski T. (eds.), Психологія здоров'я: теорія і практика (en. Health psychology: theory and practice), ЛНУ ім. I. Франка, Lviv.

Haletska I. I. (2007), Критерії психологічного здоров'я (еп. Criteria of psychological health), “Вісник Львівського університету. Філософські науки" (en. "Visnyk Lviv University. Philosophical Sciences") 10.

Haletska I. I. (2010), У пошуках свободи: внутрішня свобода як критерій психологічного здоров'я (еп. In pursuit of freedom: internal freedom as a criterion of psychological health), "Проблеми сучасної психології" (en. "Problems of modern psychology") 10.

Haletska I., Sosnowski T. (eds.) (2006), Психологія здоров'я: теорія і практика (en. Health psychology: theory and practice), ЛНУ ім. І. Франка, Lviv.

Headey B., Wearing A. (1991), Subjective Well-Being: The Stocks and Flows Framework, [in:] Strack F., Argyle M., Schwarz N. (eds.), Subjective Well-Being: an interdisciplinary perspective, $1^{\text {st }}$ ed., Pergamon Press, Oxford.

Horbal I. S. (2012a), Вилив життестійкості на задоволеність життям мешканців геріатричного пансіонату (en. Influence of hardiness on life satisfaction on geriatric homes residents), "Науковий часопис НПУ імені М. П. Драгоманова, Серія 12. Психологічні науки: Зб. наукових праць” (“Scientific journal of M. P. Dragomanov National Pedagogical University, Part 12. Psychological sciences: Compilation of scientific works") 37 (61).

Horbal I. S. (2012b), Соціально-психологічні особливості изіннісних орієнтацій у пізній дорослості (en. Social-psychological peculiarities of value orientations in late adulthood), "Проблеми загальної та педагогічної психологіiі" (en. "Problems of general and pedagogical psychology"), Збірник наукових праць Інституту психології імені Г. С. Костюка НАПНУ XIV (3).

Knyazeva E. V. (2011), Удовлетворенность жизнью как социальный феномен (еп. Life satisfaction as social phenomenon), "Вісник Харківського національного університету імені В. Н. Каразіна" (en. "Visnyk of V. N. Karazin Charkiv national university") 941.

Kulikov L. V. (2000), Детерминанты удовлетворенности жизнью (еп. Determinants of life satisfaction), [in:] Bolshakov V.O. (ed.), Общество и политика: Современные исследования, поиск концепций (еп. Society and politics: modern studies, search of concepts), Издательский дом СПбГУ, St. Petersburg.

Lewinsohn P., Redner J., Seeley J. (1991), The Relationship between Life Satisfaction and Psychological Variables: New Perspectives, [in:] Strack F., Argyle M., Schwarz N. (eds.), Subjective Well-Being: an interdisciplinary perspective, $1^{\text {st }}$ ed., Pergamon Press, Oxford.

Liders A. G. (2000), Кризис пожилого возраста: гипотеза о его психологическом содержании (еn. Crisis of old age: hypothesis of its psychological context), "Психология зрелости и старения" (en. "Psychology of maturity and obsolescence") 2.

Lyubomirsky S. (2008), The how of happiness: A scientific approach to getting the life you want, Penguin Press, New York.

Lyyra T. M., Heikkinen R. L. (2006), Perceived social support and mortality in older people, “Journals of Gerontology" Ser. B 61 (3).

Petrovskaya L. I. (ed.) (1996), Старость. Популярный справ очник (en. Old age: popular handbook), Академия, Moscow. 
Pressman S. D., Cohen S. (2005), Does positive affect influence health?, "Psychological Bulletin" 131 (6).

Ryff C., Keyes C. L. (1995), The Structure of Psychological Well-Being Revisited, "Journal of Personality and Social Psychology" 69 (4).

Ryff C., Singer B. (2008), Know Thyself and Become what You Are: A Eudaimonic Approach to Psychological Well-Being, "Journal of Happiness" 9.

Ryff C. (1989), In the Eye of the Beholder: Views of Psychological Well-Being Among Middle-Aged and Older Adults, "Psychology and Aging" 4 (2).

Schwarz N., Strack F. (1991), Evaluating One's Life: a Judgment Model of Subjective Well-Being, [in:] Strack F., Argyle M., Schwarz N. (eds.), Subjective Well-Being: an interdisciplinary perspective, $1^{\text {st }}$ ed., Pergamon Press, Oxford.

Sener A. (2011), Emotional Support Exchange and Life Satisfaction, "International Journal of Humanities and Social Science" 1 (2).

Shamionov R. M. (2006), Субъективное благополучие и цеенностно-смысловые образования личности в профессиональной срере (en. Subjective well-being and valuable and semantic formations of a person in his/her professional self-determination), “Известия Саратовского университета", Серия Философия. Психология. Педагогика (en. "News of Saratov University”, Chapter Philosophy. Psychology. Pedagogy) $6(1 / 2)$.

Sharma A. (2011), Subjective Well-Being of Retired Teachers: The Role of Psycho-Social Factors, "International Journal of Psychological Studies" 3 (1).

Stephan Y., Caudroit J., Chalabaev A. (2011), Subjective health and memory self-efficacy as mediators in the relation between subjective age and life satisfaction among old adults, "Aging \& Mental Health" 15 (4).

Strack F., Argyle M., Schwarz N. (eds.) (1991), Subjective Well-Being: an interdisciplinary perspective, $1^{\text {st }}$ ed., Pergamon Press, Oxford.

Veerhoven R. (1991), Questions on Happiness : Classical Topics, Modern Answers, Blind Spots, [in:] Strack F., Argyle M., Schwarz N. (eds.), Subjective Well-Being: an interdisciplinary perspective, $1^{\text {st }}$ ed., Pergamon Press, Oxford.

Ventegodt S., Merrick J., Andersen N. (2003), Quality of Life Theory II. Quality of Life as the Realization of Life Potential: A Biological Theory of Human Being, "The Scientific World Journal" 3.

Voronina A. V. (2002), Оченка психологического благополучия школьников в системе профилактической и коррекционной работы психологической службы: автореф. дис. ... канд. психол. наук (еп. Estimation of psychological well-being of pupils in the system of preventive and correctional work of psychological service: summary of Ph. D. thesis), Tomsk.

Yermolayeva M. А. (2002), Практическая психология старости (en. Practical psychology of old age), ЭСМО-Пресс, Moscow.

\section{NETHOGRAPHY}

Alexandrov Yu. M. (2009), Саморегуляиія як чинник психологічного благополуччя (en. Self-regulation as a factor of psychological well-being), "Вісник Харківського національного педагогічного університету імені Г. С. Сковороди", (en. "Visnyk of G. S. Skovoroda Charkiv national pedagogical university"), http://www.nbuv.gov.ua/portal/Soc_Gum/VKhnpu_psykhol/2009_32/18. html, retrieved: 14.05.2010.

Cho J., Martin P., Margrett J., MacDonald M., Poon L. W. (2011), The Relationship between Physical Health and Psychological Well-Being among Oldest-Old Adults, "Journal of Aging Research", http://www. hindawi.com/journals/jar/2011/605041/, retrieved: 19.03.2011.

Karpenko L. A., Petrovsky A. V. (eds.) (2007) Психологический лексикон. Энциклопедический словарь (Psychological lexicon. Encyclopedic dictionary), ПЕР СЭ, Moscow, http://www.insai.ru/slovar/ blagopoluchie, retrieved: 13.11.2012.

Tvorogova N. D. (ed.) (2007), Кииническая психология. Словарь, (en. Clinical psychology. Dictionary) [in:] Karpenko L. A., Petrovsky A. V. (eds.) Психологический лексикон. Энциклопедический словарь (Psychological lexicon. Encyclopedic dictionary), ПЕР СЭ, Moscow, http://www.insai.ru/slovar/ blagopoluchie, retrieved: 13.11.2012.

World Health Organization, http://www.who.int/about/definition/en/print.html, retrieved: 10.07.2012. 